\title{
ETHICAL LANGUAGE AND THEMES IN News Coverage of Genetic Testing
}

\section{David A. Craig}

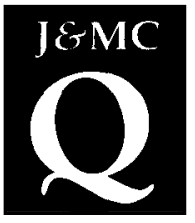

Ethical theory is employed in this study to assess news coverage of genetic testing, a topic with widely acknowledged ethical implications for professions and society. Ethical language and themes were examined in thirtyone broadcast and print stories by major news organizations in 1995 and 1996. Concerns about consequences, especially avoidance of harm, were prominent in most stories; ethical duties received less attention. Ethical themes, sometimes emerging as direct questions to readers or viewers, underlined choices facing individuals and society. Some stories powerfully brought home ethical issues without directly mentioning ethics.

Scientific knowledge of genetic links to disease is growing at a staggering pace against the backdrop of the Human Genome Project, an international effort to map all human genes. ${ }^{1}$ Discoveries in the past several years include genes linked to diseases such as breast cancer and Alzheimer's that affect millions of people. Closely following some of these discoveries has been the development of tests to determine whether people carry the genes. However, the tests can present people with extraordinarily difficult choices because, in most cases, those who test positive remain unsure whether they will get the disease. They often face the prospect of a lack of available treatment if they do test positive, and of possible insurance problems or job discrimination. The tests, therefore, present difficult ethical choices for individuals. On the organizational and professional levels, they raise questions of ethical obligation on the part of health care professionals and test developers, among others. The public importance of these ethical issues for professionals, laypeople, and policymakers points to a need for effective portrayal of the issues in news coverage-and for careful critical evaluation of this portrayal.

This article assesses news coverage of the ethical implications of genetic testing through an in-depth examination of the ethical language and themes in thirty-one stories or sidebars by major news organizations in 1995 and 1996-twelve pieces from broadcast and nineteen from print. The analytical framework for this qualitative textual analysis is grounded in the deontological and consequentialist perspectives of ethical theory.

Ethical issues have been a recognized priority within the Human Genome Project. The genome project's primary funders, the National Institutes of Health and the Department of Energy, have designated part of their genome project budgets for research on the ethical, legal, and social implications of the project. This funding has supported numerous books. ${ }^{2}$ The project is notable for its attempt to explore these implications at the same time

JEMC Quarterly Vol. 77, No. 1 Spring 2000 160-174 (이으 AEJMC
David A. Craig is an assistant professor in the H.H. Herbert School of Journalism and Mass Communication, University of Oklahoma. 
the research is proceeding, not after it is complete. Thomas H. Murray writes that the ELSI program, as it is called, "occupies a unique place in the history of science: it is the first major scientific initiative to include from its inception a commitment to systematically exploring the ethical, legal, and social issues it raises."3 Because the genome project carries widely acknowledged ethical implications, genetic testing is a particularly appropriate topic for a critical examination of the quality of major news organizations' portrayal of the ethical dimension of news.

Despite the recognized importance of ethics in the genome project, little scholarly research has addressed how journalists have covered the ethics of genetic testing - and none has assessed this coverage using ethical theory. Nelkin has noted that press coverage of biotechnology from the 1970s into the 1990s fluctuated dramatically between optimism and pessimism, with reporters sometimes raising ethical doubts. These doubts have included concern about possible genetic discrimination growing out of genetic testing. ${ }^{4}$ Despite pointing to ethical questions, however, Nelkin does not frame her assessment in terms of ethical theory.

Several other studies have addressed coverage of ethics, or lack of it, in connection with genetics-related issues. But nearly all have done so outside the explicit context of ethical theory. An exception is Hopkins' analysis of cloning coverage, which refers in passing to issues such as Kantian concerns about treating humans as means. ${ }^{5}$

Several formal studies or professional critiques center on coverage of genetic engineering, beginning with the development and debate over recombinant DNA technology in the 1970s. One early analysis found that coverage from 1974-80 in the New York Times and Washington Post focused on technical issues, not philosophical or political ones. ${ }^{6}$ Goodell argued that the press had abandoned consideration of ethical questions of genetic engineering for gee-whiz coverage at the start of the 1980 s. $^{7}$

Lewenstein, Allaman, and Parthasarathy, in a study of media coverage of biotechnology in the United States from 1970 to 1996, found that few of the stories analyzed focused on ethical issues. ${ }^{8}$ Frames used in many other stories, while not categorized in the study as ethical, related to costs and benefits, a concern of utilitarian ethics. Similarly, Priest and Talbert, in studying newspaper coverage of biotechnology in 1991 and 1992, found that only 1.3 percent of the arguments presented in the articles dealt with ethics. ${ }^{9}$ But 35.2 percent of the arguments were categorized as related to benefits and 6.2 percent to dangers-again matters of concern from a consequentialist perspective. $^{10}$

Miller, too, examined genetics-related coverage and mentioned ethics without pointing to a framework of ethical theory. He studied British media coverage after a 1993 Science article suggesting a genetic link to male homosexuality. He found that ethical implications were one of the most prominent issues in the coverage. ${ }^{11}$

Other studies have examined coverage of ethical issues in medicine and science outside the realm of genetics. But there, too, ethical theory has seldom been an explicit backdrop. Patterson and Hall did ground an analysis of public discourse about abortion in print media from the $1940 \mathrm{~s}$ to the $1990 \mathrm{~s}^{12}$ in an ethic of care. ${ }^{13}$ Studies about coverage of heart transplantation, ${ }^{14}$ the right-to-life case of Baby Jane Doe, ${ }^{15}$ and discussion of embryo research in Britain ${ }^{16}$ raise significant questions about ethics coverage but without explicitly being framed in terms of ethical theory. ${ }^{17}$ 
Taken together, previous research on coverage of genetics-and of medicine and science more generally-has provided some insight into how journalists have portrayed the ethical dimension of news. But this research has seldom assessed coverage in light of the philosophical concerns of ethical theory.

The stories analyzed appeared from March 1995 to June 1996, during a period of rapid developments in genetic research and testing. All of the stories had a significant ethics component, explicitly stated or not, and were global in scope in that they at least touched on broad issues for individuals and society, rather than just reporting a news event. However, all were tied in some way to specific events related to genetic testing-such as the unveiling of a map showing locations of most genes in the human body, the development of tests for genes linked to Alzheimer's and breast cancer, a meeting of doctors and researchers to discuss the Alzheimer's test, and the court-martial of two Marines for refusing to provide the military with samples of their DNA.

Articles by major U.S. news organizations (those with large circulations or audiences) were chosen for this analysis because, given the training of their staff members and the financial resources available to these organizations, they could be expected to provide a benchmark for the current state of ethics coverage, at least in the mainstream press. Thirty-one stories and sidebars were examined: two wire stories, thirteen newspaper pieces (other than wire stories), four newsmagazine stories, eight network television pieces, and four National Public Radio stories. ${ }^{18}$ Two newspaper commentary pieces were included in this case because of their distinctive treatment of ethics. ${ }^{19}$

The textual analysis addressed the following research question: How has the ethical dimension been evident in the content of coverage of genetic testing? More specifically, the following analytical question guided the critical reading of each story:

Does the story refer to or discuss the following issues? Little or none, some, or comprehensively? ${ }^{20}$

-Duties:

- Faithfulness to commitments

- Sensitivity to human needs

- Sensitivity to autonomy of parties

- Sensitivity to justice

- Consequences:

- Avoiding harm

- Doing good

In addition, consideration was given to questions and themes that do not always fit neatly under a single theoretical heading but whose language focuses attention on ethical issues. Also considered was, more generally, the depth of treatment of ethical issues in an effort to provide a general picture of the comprehensiveness of treatment of ethics.

A variety of ethical perspectives could have been employed in this analysis. Gilligan's relationship-oriented feminist theory ${ }^{21}$ is particularly relevant to difficult medical situations such as those created by genetic testing because of the impact of medical information and decisions on relationships. ${ }^{22}$ However, the emphasis of this exploratory analysis on duty and 
consequences is in keeping with the significance of deontological and consequentialist perspectives in the history of ethical theory-most notably, Kant and Mill-and the continuing use of these perspectives in applied ethics. ${ }^{23}$ In keeping with applied ethics as a whole, the specific ethical issues under these headings were derived from sources grounded in both philosophy and theology. Faithfulness to commitments and sensitivity to human needs were drawn from the Judeo-Christian love-based ethic as embodied in the work of Ramsey ${ }^{24}$ and May. ${ }^{25}$ The issues of autonomy, justice, avoiding harm, and doing good were drawn from the "principle-based, commonmorality" theory of Beauchamp and Childress. ${ }^{26}$ The principles from both theories reflect concerns of medical ethics but are also relevant to other professional fields.

The presentation of the textual analysis findings will include deontological and consequentialist references, ethical questions and themes, and depth of treatment of ethical issues.

Deontological and Consequentialist References. In nearly all instances, references to these categories of ethical concern were implied rather than stated directly as duties or consequences-and some passages included elements of both or encompassed more than one duty. But analysis in light of the ethical categories listed above did clearly show that consequentialist concerns, especially avoidance of harm, were prominent in most stories. Deontological references, while evident in most stories, received less attention overall.

Rick Weiss of the Washington Post provides a compelling example of presentation of potentially harmful consequences in the third and fourth paragraphs of a 2,200-word piece:

New genetic tests are moving rapidly from research laboratories into doctors' offices, where they are being marketed as a way to predict people's chances of getting common diseases such as colon cancer, breast cancer and Alzheimer's disease.

But instead of offering clear views of the future and strategies for altering it, genetic tests have raised the specters of DNAbased discrimination and loss of health insurance, and the prospect of people learning just enough to scare them but not enough to cure them. ${ }^{27}$

Without referring directly to consequences or harms, Weiss succinctly details potential negative consequences for people who get genetic tests.

A story by Tim Friend of USA Today provides another scenario of potential harm, this time from testing for forms of the APOE gene linked to Alzheimer's:

How many boomers will be tempted to check their APOE profile remains to be seen. But experts fear many are thinking as Wollin is.

A recent survey by the Alzheimer's Association's New York chapter found that $63.8 \%$ of people would have the test done even if the results are not definitive.

Experts are horrified at the prospect.

"The problem with predictive testing is there is no treatment, nothing that can be done to affect or delay, or much less 
stop the onset of the disease" says medical ethicist Daniel Callahan, The Hastings Center, Briarcliff Manor, N.Y. "It is gaining knowledge with an utter incapacity about what to do with that knowledge."28

Friend goes on to cite a Swedish researcher who learned that a person who tested positive for another Alzheimer's-related gene attempted suicide despite having genetic counseling. With this narrative, he thus makes clear to readers that getting a test, especially when nothing can be done to fight the disease, can have destructive consequences.

Likewise, to a significant degree, consequence and harm issues emerged in more than twenty other stories. Material that implied duties was also evident in most stories. However, deontological references were absent or only minimally present in ten stories.

References to duty that did emerge included all four of the duties in this study's analytical framework. For example, the manner in which some people expressed concern for the impact of testing on their families implied the duties of faithfulness to commitments and sensitivity to the needs of others. In a National Public Radio story by Joe Palca ${ }^{29}$ on a Michigan family's struggle with breast cancer and genetic testing, one woman had learned that she did not carry the genetic marker for breast cancer-but that her nieces did. Her reaction portrayed her ethical concern:

It was one thing, my sisters having inherited the gene, but it was quite another, my nieces, because I'll tell you, my nieces and nephews are like my own kids, and if there was any way that I could take that away from them, that pain, I'd just - I just couldn't deal with it. I thought, "Why couldn't it be me," you know, "instead of them?" It was just devastating to find out that these young people were affected with this and that they had to worry about this and that they had to go through all this, and I think that's what hit everybody in the family worst. ${ }^{30}$

By using "Susan's" own words at length, Palca powerfully portrayed her commitment to her nieces and their needs, bringing home to listeners the ethical issues that someone with a difficult family genetic history might face. ${ }^{31}$ References to human dilemmas and commitments were a strong thread in many of the stories analyzed.

Language that pointed to issues of autonomy and justice also appeared in many stories, primarily in relation to concerns about possible misuse of genetic testing results by insurance companies or employers. For example, Christine Gorman of Time used an anecdote to illustrate problems with insurance. It opens in language of direct address to engage the reader:

Consider the case of Vickie Reis, a 42-year-old farmer who lives in Northern California. Six years ago, Reis told an emergency-room doctor treating her for bronchitis that her sister had died of cystic fibrosis, an incurable lung ailment. The physician then tested the woman and found that she bore a single copy of the CF gene. But as any first-year genetics student knows, it takes two copies of the damaged gene for a person to develop this disease. Even so, Reis' medical record subsequently contained the information about her cf gene, and she was repeatedly 
denied health insurance. "I had never had any symptoms of the disease," she notes. "But the fact that I carried the gene was enough to leave a big shadow on my medical history. ${ }^{\prime 32}$

This case implies a violation of Reis' autonomy because it involves unwanted interference with her ability to choose to have health insurance. It also implies an injustice because the denial of insurance apparently was based on poor medical evidence.

An $\mathrm{ABC}$ News piece by George Strait also raises issues of autonomy and justice. He quotes a woman whose grandson was denied medical insurance because his mother had a genetic heart defect, then follows with a comment from George Annas, an expert on health law and ethics:

DORIS GOLDMAN: Something is terribly wrong when a healthy little boy is denied health coverage based on genetic makeup.

Prof. GEORGE ANNAS, Boston University: I believe we should have a very firm rule that no one looks at our genetic information without our informed consent and no one stores our DNA samples for future testing without our informed consent as well. ${ }^{33}$

Unlike Gorman's piece, this one uses an ethicist's formal language of informed consent - an important element of autonomy in medical ethics. ${ }^{34} \mathrm{But}$ the autonomy issue is embedded in both accounts. Justice, too, is evident in Strait's story when Goldman exclaims that "Something is terribly wrong" with her grandson's denial of insurance. Whether in the colloquial language of emotion or the formal language of ethical deliberation, ethics emerges in these two stories.

Thus, while some of the stories analyzed leave matters of duty unaddressed or little developed, others bring home issues to audiences that are significant from a deontological standpoint.

Given the broad importance of genetic testing in society, it is also significant that the duties which emerged involved both individualsprofessionals and non-professionals-and institutions. Although testing's impact on individual non-professionals - and the public as a whole-was a significant element in many stories, most of them at least implied duties on the part of professionals and institutions, including genetic testing companies, biotechnology firms, insurance companies, doctors, genetic counselors, and other health care professionals. A particularly strong thread among stories is the need for the health care profession-or other professions-to provide genetic counseling.

Ethical Questions and Themes. In addition to assessing the stories for deontological and consequentialist content, this study included elements that did not always fit neatly into a single ethical category but did embody ethical themes-that is, problems that can be addressed through moral reasoning. ${ }^{35}$ These themes, sometimes stated as questions, confronted readers with the moral choices that arise from genetic testing.

Four themes emerged as most prominent in the stories as a whole; each appeared in at least seven of the stories. These themes overlap, but they differ enough that they can be usefully discussed as distinct themes.

Theme 1. Whether you want to know your likely medical future. In some cases, the theme of knowing your future was stated with greater certainty 
than the probabilistic nature of the testing allows, ${ }^{36}$ but regardless, this theme figured prominently in several stories. It was sometimes presented in tandem with Theme 2: what you would do with the information.

Several stories stated the first theme in questions that opened and therefore framed the story. Robert Bazell's NBC News overview on genetic testing opened with these words read by Tom Brokaw: "Tonight we take a look at genetic testing. If you could know your future, life or death, illness or health, good or bad, would you choose to know? Would you want your insurance company to know?"37 Because this story is framed with questions of whether "you" would want to choose or know-questions stated in the authoritative voice of the network anchor-it brings this ethical theme strongly and directly to viewers.

Likewise, Palca's NPR piece on the Michigan family opened with these words from Robert Siegel, the host of All Things Considered: "In the last few years, geneticists have learned how to predict the medical future for some patients, telling them whether they'll get cancer, for example. These tests are not widely used now, but they are expected to be-soon. The question is, do people really want this kind of predictive information, and if they have it, what will they do with it?"38

Although Palca did not present the questions in the second personhe used "people" and "they" rather than "you" - he still brings the themes to his audience in the form of a question, implying the need for the listener to consider an answer.

Theme 2. What you would do with the information. This theme followed logically from the question of whether you would want to know your likely medical future.

However, Diane Egner, a Tampa Tribune editorial writer, set out Theme 2 separately by stating specific questions that would connect with readers' own lives:

To begin to understand the complexities of the situation, imagine being told that you carry a gene mutation indicative of the early onset of Alzheimer's disease.

How would it change your lifestyle? Would you decide to pack 30 years of travel into 10 ? Would you retire early? Would you move closer to your children or grandchildren? Would you handle your finances differently or vow to lead a more moral life? Would you be angry, sad, disappointed or happy to know? ${ }^{39}$

Egner thus makes concrete some of the possible impacts that genetic information would have on a personal level.

Theme 3. The complexity of the choices people face because of developments in genetic testing. While at some points reporters presented questions reflecting actual choices (Themes 1 and 2), at other points through statements and stories they focused on the agonizing nature of the choices (Theme 3 ).

This theme emerges in Diane Eicher's story in the Denver Post about another family's struggle over breast cancer testing:

But the results of the test would have an impact that reached far beyond Katie's health. If she did have the mutation, then other female relatives in the family also would be at risk for it. 
Would her sister, Sharon, want to be tested? What about Sharon's teenage daughters?

"My biggest concerns were my nieces if I were positive, then that means they're at increased risk," said Katie. "And they're too young to even have to be thinking about this." (Testing for the breast cancer gene usually isn't done on anyone under 18, said Arfa.)

Knowing that a family carries a cancer gene could carry another price. If insurance companies that cover her relatives discovered the situation, would they provide coverage? If so, would rates skyrocket?

Clearly, Katie's decision whether to have the test was problematic-and momentous. And in the middle of this discussion, as Rae also watched her daughter fight breast cancer, she was frequently overcome with guilt and sadness. ${ }^{40}$

By weaving together statements about the situation in her own words with questions and quotes, Eicher showed readers the difficulty of this woman's decision-and therefore pointed to the difficulties other families will face.

Theme 4. The possibility of discrimination based on genetic information. This theme was sometimes evident through the use of the emotionally laden word "discrimination" itself and sometimes through description and example. For example, Tim Friend of USA Today wrote a front-page brief ${ }^{41}$ and a story inside the front section ${ }^{42}$ that included description of legislative and policy action related to genetic discrimination. As he summarized in the short frontpage piece:

Eleven states have enacted laws against discrimination on the basis of genetic information; Congress and most states are considering such laws, says Kay Johnson, lobbyist for the March of Dimes.

The Pentagon said Thursday it has instituted a new policy that restricts access and uses of the DNA samples of military personnel. The announcement comes as two Marines face a court-martial hearing for refusing to submit to DNA testing. $^{43}$

In addition to these stories by Friend, ten other stories mentioned discussion or passage of legislation at the state and federal levels to prevent discrimination based on genetic test results. Two network television pieces dealt with the two Marines' objection to the military's DNA testing based on concerns about possible discrimination. ${ }^{44}$ The theme of discrimination-one with ethical as well as legal overtones-thus was prominent, too, in the body of stories analyzed. Although this theme relates to the ethical duty of justice, it also represents a potential consequence of genetic testing. Therefore, it, like the other themes, does not fit neatly into a single ethical box.

Depth of Treatment of Ethical Issues. Consideration of the depth of handling of the ethical dimension cannot be entirely separated from consideration of references to duty and consequence and from ethical questions and themes. However, the stories raise another significant issue related to depth in ethics in that they often dealt with ethical issues without explicit reference to ethics. Of the thirty-one pieces analyzed, fourteen included no use of the word "ethics" or its cognate terms, except occasionally in citing an "ethicist" 
as a source. In addition, only a smattering of ethicists appear as sources in the stories analyzed. A total of five ethicists or philosophers were interviewed in six stories. The absence of direct references to ethics and ethicists should at least raise a question about these stories' ethical depth because this explicit language and sourcing can so clearly point to the ethical dimension.

It would be inappropriate, however, to conclude that the absence of ethicists or references to ethics means these stories are automatically deficient in their handling of ethics. Ethics is embedded in the discussions of professional and personal choices posed by genetic testing as those choices are portrayed in the articles. For example, a story by Gina Kolata of the New York Times ${ }^{45}$ portrayed the dilemmas confronting doctors because of the discovery that a test which reveals genetic susceptibility to heart disease also points to a higher risk of Alzheimer's disease. Among the difficult choices that physicians face is whether to inform patients who test positive in connection with investigation of heart disease that the test also shows greater susceptibility to Alzheimer's. Kolata's 1,700-word story effectively portrays the difficulty of such moral choices from the standpoint of professionals-by using professionals and a patient, not ethicists, as sources for quotes and an anecdotal lead.

Bazell of NBC provides an example of effective portrayal of human dilemmas without using the word "ethics." He portrayed the choices facing the family of Gerry Harvell, a woman who tested positive for Huntington's disease, meaning she was virtually certain to develop the degenerative disorder that killed her mother. As Bazell put it:

Gerry's brothers and sisters had to make their own decisions. Her brother Jeff decided not to know his genetic future. JEFF: Why take the test and dwell on what the test results are and waste more time? Because now, I have four children. And my focus right now is the importance of all those children and my wife. ${ }^{46}$

This man faced choices with a moral component because, as he recognized, his decision would affect his family, for good or ill. By presenting the dilemmas of Gerry Harvell and her family, in both his words and theirs, Bazell thus brought home the ethical dimension on the individual level, underlining the fact that reporters can powerfully portray the ethical import of genetic testing through other choices of words.

\section{Discussion}

Consequentialist concerns, especially avoidance of harm, emerged prominently in the language of most stories analyzed. At the same time, deontological references, while present in most cases, were absent or only minimally present in a substantial number of stories. However, material that addressed ethics was not limited to references that could be clearly classified as deontological or consequentialist. Ethical themes, sometimes emerging as direct questions to readers and viewers, underlined the choices facing individuals and society. And often the ethical dimension emerged in the text without explicit reference to ethics.

The quality of these stories' coverage of the ethical dimension of genetic testing can be further assessed in the context of C.E. Harris's discussion of types of moral judgment, ${ }^{47}$ in which he distinguishes among actions 
that are morally obligatory, morally permissible, and morally impermissible. A fourth category for Harris, supererogatory acts, are those that are "above and beyond the call of duty." 48 Given the limitations on journalists posed by many factors including time and space constraints, full coverage of the ethical dimension in all stories-or even most stories-is supererogatory. The sense of moral obligation assumed in this study acknowledges these constraints and suggests that some coverage of the ethical dimension should be evident in some stories.

Even if one assumes that the news media have a moral obligation to cover important issues in society, it would be, in Harris' terms, supererogatory to expect every story on genetic testing issues to provide a comprehensive portrayal of duties and consequences or ethical themes. Taken together, the stories analyzed reflect both strong and weak points in their portrayal of ethics. As a group, they are skewed in a consequentialist direction, and many do not mention "ethics" or related words specifically at all. At the same time, the stories present important ethical questions and themes. A reader or viewer of even a few of these stories would likely find his or her knowledge of the ethical dimension of genetic testing advanced in significant ways. The stories here, as a group, fall into the "morally obligatory" category from the standpoint of journalistic obligation.

Still, given the importance of genetic testing issues for professionals, public, and policymakers, it is worth asking whether the articles could have done more to build readers' understanding of the relevant ethical concerns and more effectively laid the groundwork for public discussion of issues, as journalists practicing forms of civic or public journalism have attempted to do in recent years. ${ }^{49}$ Stories that address consequences of genetic testing at least provide the public information that may aid personal decision making. Those stories that imply duties on the part of individuals may also provide food for personal thought. However, the stories that touch on professional and institutional duties begin to lay the groundwork for people to express their opinions at the level of institutional and public policy or to influence professional practice. To the extent the stories addressed both levels, they became-at least potentially-both personally and civically useful. Journalists could improve future coverage - and its potential to foster understanding and discussion-by more fully portraying ethical duties at levels beyond the individual.

Stories that stated ethical questions and themes, whether clearly deontological or consequentialist or not, also have the potential to foster public understanding. By focusing the ethical discussion on one or a few themes, these stories give lay readers "handles" for grasping the potential impact of genetic testing decisions on themselves, their families, or others like them. ${ }^{50}$ By understanding this impact, members of the public may become better equipped to press for change-though future research needs to explore how audiences actually process stories with ethical themes.

In addition to attempting to portray duties more fully, journalists should consider how they can address ethics more explicitly, in at least some stories. Despite the fact that some stories in this case powerfully portrayed moral choices without referring directly to ethics, it is still reasonable to argue that if the stories are to address ethical implications comprehensively, more of them should refer explicitly to the ethical dimension. The use of the word (or words) might make no difference for some readers or viewers, but it at least would confront them directly with the fact that ethical choices are involved. Similarly, use of ethicists as sources is not a panacea for covering 
ethics, but given the expertise of competent ethics scholars, it also seems reasonable to expect to see more of them quoted in the stories.

This article contributes to current scholarly understanding of ethics coverage by assessing a body of coverage of a topic with widely recognized ethical implications for professions and society, and by carrying this assessment out using an analytical approach grounded in perspectives widely embraced in ethical theory. Further research on ethics coverage could fruitfully examine coverage of other ethics-laden topics through this theoretical lens.

\section{NOTES}

1. For an overview of the project, see "The Human Genome Project" [World Wide Web document] (The National Human Genome Research Institute, National Institutes of Health, accessed 4 January 2000); available from http:/ / www.nhgri.nih.gov/HGP; Internet.

2. M. Susan Lindee, "The ELSI Hypothesis," Isis 85 (June 1994): 293-96. Among the books are George J. Annas and Sherman Elias, eds., Gene Mapping: Using Law and Ethics As Guides (NY: Oxford University Press, 1992); Daniel J. Kevles and Leroy Hood, eds., The Code of Codes: Scientific and Social Issues in the Human Genome Project (Cambridge, MA: Harvard University Press, 1992); Mark S. Frankel and Albert Teich, eds., The Genetic Frontier: Ethics, Law, and Policy (Washington, DC: American Association for the Advancement of Science, 1994); Timothy F. Murphy and Marc A. Lappe, eds., Justice and the Human Genome Project (Berkeley, CA: University of California Press, 1994); Thomas H. Murray, Mark A. Rothstein, and Robert F. Murray, Jr., eds., The Human Genome Project and the Future of Health Care (Bloomington, IN: Indiana University Press, 1996); Mark A. Rothstein, ed., Genetic Secrets: Protecting Privacy and Confidentiality in the Genetic Era (New Haven, CT: Yale University Press, 1997); and Maxwell J. Mehlman and Jeffrey R. Botkin, Access to the Genome: The Challenge to Equality (Washington, DC: Georgetown University Press, 1998).

3. Thomas H. Murray, "Speaking Unsmooth Things about the Human Genome Project," in Annas and Elias, Gene Mapping, 250.

4. Dorothy Nelkin, Selling Science: How the Press Covers Science and Technology, rev.ed. (NY:W.H. Freeman, 1995), 35-37. See also Dorothy Nelkin and M. Susan Lindee, The DNA Mystique: The Gene As Cultural Icon (NY:W.H. Freeman, 1995); Dorothy Nelkin, "Covering Gene Therapy: Beware the Hype," Quill, September 1996, 34-37; and Celeste M. Condit, Nneka Ofulue, and Kristine M. Sheedy, "Determinism and Mass-Media Portrayals of Genetics," American Journal of Human Genetics 62 (April 1998): 979-84.

5. Patrick D. Hopkins, "Bad Copies: How Popular Media Represent Cloning As an Ethical Problem," Hastings Center Report, March-April 1998, 613. See also a brief commentary by Leigh Turner, "The Media and the Ethics of Cloning," Chronicle of Higher Education, 26 September 1997, B4-B5.

6. Michael Altimore, "The Social Construction of a Scientific Controversy: Comments on Press Coverage of the Recombinant DNA Debate," Science, Technology, \& Human Values 7 (fall 1982): 24-31.

7. Rae Goodell, “The Gene Craze," Columbia Journalism Review, November-December 1980, 41-45. See also Nancy Pfund and Laura Hofstadter, "Biomedical Innovation and the Press," Journal of Communication 31 (spring 1981): 138-54; and Rae Goodell, "How to Kill a Controversy: The Case of 
Recombinant DNA," in Scientists and Journalists: Reporting Science As News, ed. Sharon M. Friedman, Sharon Dunwoody, and Carol L. Rogers (NY: Free Press, 1986), 170-81.

8. Bruce V. Lewenstein, Tracy Allaman, and Shobita Parthasarathy, "Historical Survey of Media Coverage of Biotechnology in the United States, 1970 to 1996" (paper presented at the annual meeting of the AEJMC, Baltimore, MD, 1998).

9. Susanna Hornig Priest and Jeffery Talbert, "Mass Media and the Ultimate Technological Fix: Newspaper Coverage of Biotechnology," Southwestern Mass Communication Journal 10 (1, 1994): 76-85. See also Susanna Hornig Priest, "Structuring Public Debate on Biotechnology: Media Frames and Public Response," Science Communication 16 (December 1994): 166-79, and Susanna Hornig Priest, "Information Equity, Public Understanding of Science, and the Biotechnology Debate," Journal of Communication 45 (winter 1995): 39-54.

10. Likewise, Altimore's study, "The Social Construction of a Scientific Controversy," coded statements about benefits as scientific or technical, not philosophical.

11. David Miller, "Introducing the 'Gay Gene': Media and Scientific Representations," Public Understanding of Science 4 (July 1995): 269-84.

12. Maggie Jones Patterson and Megan Williams Hall, "Abortion, Moral Maturity and Civic Journalism," Critical Studies in Mass Communication 15 (June 1998): 91-115.

13. Carol Gilligan, In a Different Voice: Psychological Theory and Women's Development (Cambridge, MA: Harvard University Press, 1982). Patterson and Hall concluded that "the feminine means of moral reasoning" (Patterson and Hall, "Abortion, Moral Maturity and Civic Journalism," 92) has gradually emerged to prominence in discussion of abortion.

14. William R. Oates, "Social and Ethical Content in Science Coverage by Newsmagazines," Journalism Quarterly 50 (winter 1973): 680-84.

15. Stephen Klaidman and Tom L. Beauchamp, "Baby Jane Doe in the Media," Journal of Health Politics, Policy and Law 11 (summer 1986): 271-84. In addition, Kathleen Kerr, the lead reporter for Pulitzer Prize-winning coverage by Newsday, discussed how the coverage developed in "Reporting the Case of Baby Jane Doe," Hastings Center Report, August 1984, 7-9.

16. Michael Mulkay, "Embryos in the News," Public Understanding of Science 3 (January 1994): 33-51.

17. A variety of literature on risk communication has touched on ethics, directly or indirectly. See, for example, Risky Business: Communicating Issues of Science, Risk, and Public Policy, ed. Lee Wilkins and Philip Patterson, with a foreword by Dorothy Nelkin (NY: Greenwood Press, 1991) and Lee Wilkins, "Between Facts and Values: Print Media Coverage of the Greenhouse Effect, 1987-1990," Public Understanding of Science 2 (January 1993): 71-84.

18. Media outlets for which stories were coded were: Religion News Service (articles as published in the Cleveland Plain Dealer), Chicago Tribune, Denver Post, Louisville Courier-Journal, Minneapolis Star Tribune, New York Times, Tampa Tribune, USA Today, Washington Post, Time, U.S. News E World Report, ABC News, CBS News, NBC News, and National Public Radio. Text of the specific stories was obtained primarily through Lexis-Nexis but also through Burrelle's broadcast news and Dialog databases. Videotapes of the broadcast pieces were obtained from the Vanderbilt University Television News Archive.

19. About eighty relevant stories from early 1995 to mid-1996 that were 
initially considered referred at least in passing to "ethics" or its cognate words along with genetic research, testing, or counseling-or evidenced ethical content in other ways. The list of stories was narrowed for in-depth qualitative analysis to those that on a preliminary reading were found to deal most substantially and distinctively with the ethics of genetic testing. Additionally, some stories from early to mid-1995 were excluded to focus on stories that reporters would more likely recall in interviews carried out as part of a larger study. A few early broadcast and newsmagazine stories were retained to maximize the variety of media in this exploratory analysis.

20. "Some," "little," and "comprehensive" were defined by story with recognition of the limitations imposed by space and time constraints and other factors. These categories were not used to rate coverage quantitatively on an enumerated hierarchy but rather to shape exploratory, qualitative textual analysis aimed at beginning to map the terrain of ethics coverage. The analytical question employed in this article is one of several drawn from a theoretical framework for assessing ethics coverage developed and applied in the author's dissertation. See David A. Craig, "Covering the Ethics Angle: Toward a Method to Evaluate and Improve How Journalists Portray the Ethical Dimension of Professions and Society" (Ph.D. diss., University of Missouri-Columbia, 1997) and David A.Craig," A Framework for Evaluating Coverage of Ethics in Professions and Society," Journal of Mass Media Ethics 14 $(1,1999): 16-27$. This genetic testing study originated in the dissertation.

21. Gilligan, In a Different Voice.

22. The author thanks an anonymous reviewer of a previous version of this study, presented as David A. Craig, "A Critical Assessment of News Coverage of the Ethical Implications of Genetic Testing" (paper presented at the annual meeting of the AEJMC, Baltimore, MD, 1998), for noting the applicability of Gilligan to the analysis in this case.

23. Both perspectives are cited, for example, in media ethics in Clifford G. Christians, Mark Fackler, Kim B. Rotzoll, and Kathy Brittain McKee, Media Ethics: Cases and Moral Reasoning, 5thed.(NY:Longman, 1998), 13-16. Edmund B. Lambeth argues for a mixed deontological framework that draws on both of these perspectives in Committed Journalism: An Ethic for the Profession, 2 d ed. (Bloomington, IN: Indiana University Press, 1992), 21-22. Both perspectives are cited in connection with medical ethics in the discussion of ethical theories in Tom L. Beauchamp and James F. Childress, Principles of Biomedical Ethics, 4th ed. (NY: Oxford University Press, 1994), 47-62.

24. Paul Ramsey, Basic Christian Ethics (NY: Charles Scribner's Sons, 1950); Paul Ramsey, The Patient as Person: Explorations in Medical Ethics (New Haven, CT: Yale University Press, 1970).

25. William F. May, The Patient's Ordeal (Bloomington, IN: Indiana University Press, 1991). Faithfulness to commitments calls for ongoing, even long-term, action in the interest of another person, simply because he or she is a person. Sensitivity to human needs calls for placing a high priority on meeting the concrete needs of individuals. The love-based ethic applied in this framework has much in common with Gilligan's ethic of care. She states that women's moral concern tends to include "[s]ensitivity to the needs of others and the assumption of responsibility for taking care" (Gilligan, In a Different Voice, 16), notions that are closely tied to the duties of sensitivity to human needs and faithfulness to commitments.

26. Beauchamp and Childress, Principles of Biomedical Ethics, 100-109. Beauchamp and Childress define autonomy as "personal rule of the self that is free from both controlling interferences by others and from personal 
limitations that prevent meaningful choice, such as inadequate understanding" (121). They note that various philosophers "interpret justice as fair, equitable, and appropriate treatment in light of what is due or owed to persons" (327). Although avoiding harm (nonmaleficence) and doing good (beneficence) appear as duties in Beauchamp and Childress, they are included instead under the consequentialist heading in this analysis because of the importance of benefits and harms in consequentialist ethics. It was determined that including them under both duty and consequence headings would have needlessly confused the analysis.

27. Rick Weiss, "Tests' Availability Tangles Ethical and Genetic Codes," Washington Post, 26 May 1996, sec. A, p. 1 (Final).

28. Tim Friend, "Looking for Alzheimer's: Test Identifies Gene but Can't Predict Disease," USA Today, 20 May 1996, sec. D, p. 1.

29. Joe Palca, news report, All Things Considered, NPR, 29 June 1995.

30. Palca, All Things Considered, 29 June 1995.

31. Or, stated in terms of Gilligan's theory (Gilligan, In a Different Voice), he portrayed Susan's concern about relationships-in light of the profound impact that genetic information can have on individuals and families.

32. Christine Gorman, "The Doctor's Crystal Ball," Time, 10 April 1995, p. 60.

33. George Strait, news report, ABC World News Tonight, 15 April 1996.

34. Beauchamp and Childress, Principles of Biomedical Ethics, 128.

35. Ethical themes in the stories appeared in individual phrases, questions or other sentences, or as threads running through a number of statements by the reporter or sources for the story. The sense of the term used here is modified from its use by bioethicist Arthur Caplan in a telephone interview by the author, 23 October 1996, and in personal communication, 15 December 1996. Although this is not a formal philosophical term, it emerged as useful during a related case study because it provides a way of assessing ethical content along lines other than explicitly philosophical duties or principles.

36. Greg Sachs, assistant director, MacLean Center for Clinical Medical Ethics, University of Chicago, telephone interview by author, 19 May 1997.

37. Robert Bazell, news report, NBC Nightly News, 6 July 1995.

38. Palca, All Things Considered, 29 June 1995.

39. Diane Egner, "Bitter Fruit," Tampa Tribune, 3 December 1995, Commentary, p. 1 (Metro).

40. Diane Eicher, “Genetic Tests: a Catch-22," Denver Post, 29 May 1996, sec. G, p. 1 (2d).

41. Tim Friend, "Genetic Findings Used to Deny Jobs, Coverage," USA Today, 12 April 1996, sec. A, p. 1 (Final).

42. Tim Friend, "Researchers Uncover Genetic Discrimination," USA Today, 12 April 1996, sec. A, p. 3 (Final).

43. Friend, "Genetic Findings," sec. A, p. 1.

44. Robert Bazell, news report, NBC Nightly News, 15 April 1996; George Strait, news report, ABC World Nezws Tonight, 15 April 1996.

45. Gina Kolata, "If Tests Hint Alzheimer's, Should a Patient Be Told?" New York Times, 24 October 1995, sec. A, p. 1 (Late-Final).

46. Bazell, NBC Nightly News, 6 July 1995.

47. C.E. Harris Jr., Applying Moral Theories, 2d ed. (Belmont, CA: Wadsworth, 1992), 58-59. Harris's categories are a key element in the theoretical framework developed in Craig, "Covering the Ethics Angle" and Craig, "A Framework for Evaluating Coverage of Ethics."

48. Harris, Applying Moral Theories, 59. 
49. Publications that explore the thinking and doing of civic/public journalism include Jay Rosen and Davis Merritt Jr., Public Journalism: Theory and Practice (Dayton, OH: Kettering Foundation, 1994); Arthur Charity, Doing Public Journalism (NY: Guilford, 1995); Davis Merritt, Public Journalism and Public Life: Why Telling the News Is Not Enough, 2d ed. (Mahwah, NJ: Lawrence Erlbaum Associates, 1998); Edmund B. Lambeth, Philip E. Meyer, and Esther Thorson, eds., Assessing Public Journalism (Columbia, MO: University of Missouri Press, 1998); and Theodore L. Glasser, ed., The Idea of Public Journalism (NY: Guilford, 1999). Susanna Hornig Priest argues for public influence on the direction of genetic research, a position she contends is consistent with public journalism. See Priest, "Popular Beliefs, Media, and Biotechnology," in Communicating Uncertainty: Media Coverage of New and Controversial Science, ed. Sharon M. Friedman, Sharon Dunwoody, and Carol L. Rogers (Mahwah, NJ: Lawrence Erlbaum Associates, 1999), 98.

50. This discussion of the possible benefits of choosing one or a few themes in an ethics story draws on a telephone interview by the author with Thomas Billitteri, a former editor for Religion News Service, 22 July 1996, in which he referred to the notion of a "first-generation" story that addresses only key issues connected with a complex subject. 